\title{
Evaluation of carinata meal as a feedstuff for growing dairy heifers: Effects on growth performance, rumen fermentation, and total-tract digestibility of nutrients
}

\author{
K. Rodriguez-Hernandez* $†$ and J. L. Anderson*1 \\ *Dairy and Food Science Department, South Dakota State University, Brookings 57007 \\ †C. E. La Laguna, Instituto Nacional de Investigaciones Forestales, Agrícolas y Pecuarias, Coahuila 27440, México
}

\begin{abstract}
Our objective was to determine the effects of feeding carinata meal (CRM) compared with distillers dried grains with solubles (DDGS) on growth performance, rumen fermentation, and nutrient utilization in peripubertal dairy heifers. A 16-wk randomized block design experiment with 24 Holstein heifers $[6.6 \pm 0.7 \mathrm{mo}$ and $218 \pm 27 \mathrm{~kg}$ of body weight (BW)] was conducted. Treatments diets were (1) 10\% cold-pressed CRM and (2) $10 \%$ DDGS on a dry matter (DM) basis. The remainder of the diets consisted of grass hay, ground corn, soybean meal, and mineral mix. Diets were formulated to be isonitrogenous and isocaloric. Heifers were individually fed using a Calan gate feeding system, and the rations were limit-fed at $2.65 \%$ of $\mathrm{BW}$ on a DM basis to target a $0.8 \mathrm{~kg} / \mathrm{d}$ of average daily gain. Heifers were weighed every 2 wk and the ration amount offered was adjusted accordingly. Frame sizes, BW, and body condition scores were measured 2 d every 2 wk throughout the study. During wk 12 and 16, rumen fluid samples were collected via esophageal tubing for $\mathrm{pH}$, ammonia $\mathrm{N}$, and volatile fatty acid analyses. In wk 16, fecal grab samples were collected for apparent total-tract digestibility estimation. Heifer DM intake, BW, average daily gain, and gain:feed were similar between treatments. No differences were observed between treatments in frame measurements or body condition scores. Rumen $\mathrm{pH}$ tended to be greater in CRM compared with DDGS. Rumen ammonia $\mathrm{N}$ and total volatile fatty acid concentration were not different between treatments. Apparent total-tract digestibility of DM, neutral detergent fiber, and acid detergent fiber were decreased in CRM compared with DDGS. A tendency was detected for reduced organic matter digestibility in CRM. No difference was observed between treatments for crude protein total-tract digestibility. However, these differ-
\end{abstract}

Received July 27, 2017.

Accepted September 26, 2017.

${ }^{1}$ Corresponding author: jill.anderson@sdstate.edu ences in total-tract nutrient digestibility were not large enough to influence growth performance. Overall, results demonstrated that growing heifers can be limit-fed diets with 10\% CRM and maintain growth performance compared with a control diet containing 10\% DDGS. Key words: dairy heifer, carinata meal, growth performance

\section{INTRODUCTION}

One of the priorities for dairy producers is to decrease the cost of raising heifers through strategies that optimize the growth of the heifers and minimize cost without sacrificing productivity (Gabler et al., 2000; Tozer and Heinrichs, 2001). One option to decrease costs is to use less expensive co-products from the growing renewable biofuels industry. Co-products such as distillers dried grains or canola meal are 67.8 and $23.6 \%$, respectively, less expensive than soybean meal (Gould, 2017). Additionally, government programs are focused on increasing the use of renewable fuels (US Department of Energy, 2015). These circumstances are encouraging the development of new feedstocks to produce biofuels, and hence the possibility of new feedstuffs that could be used to feed dairy replacement heifers.

One feedstock of new and increasing interest in the Great Plains is carinata (Brassica carinata) because of its high oil content and unique fatty acid profile that is favorable for biofuel production. It also has promising agronomic properties, such as good adaptation to dry climates and could be grown in areas where other more common crops cannot adapt (Marillia et al., 2014). Carinata oilseeds have been genetically selected to have very high concentrations of very-long-chain fatty acids, such as erucic acid (C22:1), which can be used to produce biofuels and bio-oils more efficiently compared with other oilseeds (Cardone et al., 2003; Enjalbert et al., 2013). After the oil extraction, the resulting carinata meal has high content of rumen degradable protein, which has a total protein digestibility comparable 
to that of soybean and linseed meals (Lawrence and Anderson, 2015).

A disadvantage of carinata meal is that it contains glucosinolates, which are anti-nutritional compounds. Glucosinolates are present in plants of the Brassicaceae family (rapeseed, camelina, and carinata). By themselves glucosinolates are innocuous, but when the vegetative parts of the plant are damaged, they are degraded and may cause bitter taste and irritate the mucus membranes (Duncan and Milne, 1993; Majak, 2001), therefore potentially decreasing the palatability of these oilseed meals. However, ruminants generally can tolerate diets of $10 \%$ rapeseed meal, which also contains glucosinolates (Brown, 2014). Some glucosinolates decrease the thyroid function through interference with iodine uptake, potentially affecting the growth and animal performance (Forss and Barry, 1983; Duncan and Milne, 1992; Geertmann et al., 1994; Tsao et al., 2000; Tripathi and Mishra, 2007; Marillia et al., 2014).

Thus, the objective of this research was to conduct an initial study to determine the effects of feeding carinata meal on growth performance, rumen fermentation, and nutrient utilization of peripubertal dairy heifers compared with a control diet containing distillers dried grains with solubles. We hypothesized that, as carinata meal has high CP content and quality, its inclusion in the diet at 10\% (DM basis) would maintain or enhance the growth performance of dairy heifers without negatively affecting rumen fermentation or nutrient digestibility compared with the control diet.

\section{MATERIALS AND METHODS}

All animal procedures and uses were approved by the South Dakota State University Institutional Animal Care and Use Committee, protocol number 15-060A. The institutional Animal Welfare Assurance number filed with the Health Service Office for Protection from Research Risks is \#A3958-01.

\section{Experimental Design}

To meet our objectives a 16 -wk randomized complete block design feeding study was conducted using 24 Holstein heifers $(6.6 \pm 0.7$ mo of age and $218 \pm 27 \mathrm{~kg}$ of BW) with 2 treatment diets. The feeding study was conducted over 11 mo from August 2015 to June 2016 at the South Dakota State University Dairy Research and Training Facility (Brookings, SD). Heifers were blocked in groups of 2 based on birthdate and body weights. Heifers were randomly assigned to treatment after assignment to block. Heifers were added on the study in groups of 6 animals or 3 blocks at different times based on age and availability with a target starting age of 6.5 mo. Heifers were habituated to the research barns and feeding system for $2 \mathrm{wk}$, followed by an experimental feeding period of $16 \mathrm{wk}$.

Treatments diets were (1) cold-pressed carinata meal (CRM) and (2) distillers dried grains with solubles (DDGS), both at $10 \%$ of the diet on a DM basis. The DDGS was chosen as a control diet and for comparison as it has been shown it can replace corn and soybean meal in dairy heifer diets (Anderson et al., 2015; Manthey et al., 2016). Additionally, the fat content of DDGS also allowed for a closer total fat content between diets when compared with other common protein sources. The remainder of the diets were composed of grass hay, ground corn, soybean meal, and mineral mix to meet nutrient requirements and formulated to allow for similar intakes of protein and energy between treatments (Table 1). The dietary inclusion of $10 \%$ as CRM was used as it is the limit established by the FDA for rapeseed meals, which are from a similar plant family and have similar glucosinate concentrations (Benz, 2010). The 2 treatment diets were both limit-fed at $2.65 \%$ of $\mathrm{BW}$.

\section{Animal Care and Feeding}

Heifers were observed daily for any injury or disease problems and treated according to normal farm management practices at the Dairy Research and Training Facility. Heifers were housed in pens in groups of 6 heifers. Each pen had an inside roofed area $(7 \mathrm{~m} \times 4$ $\mathrm{m})$ and an outside soil exercise lot $(7 \mathrm{~m} \times 23.5 \mathrm{~m})$. The inside areas of the pens were manure pack and bedded with straw once per week to discourage consumption of straw.

Table 1. Ingredient composition of diets with carinata meal (CRM) and distillers dried grains with solubles (DDGS) fed to growing dairy heifers $^{1}$

\begin{tabular}{lrc}
\hline & \multicolumn{2}{c}{ Diet $^{1}$} \\
\cline { 2 - 3 } Ingredient, \% of DM & CRM & DDGS \\
\hline Grass hay & 63.53 & 63.53 \\
Carinata meal & 10.00 & - \\
DDGS & 14.51 & 10.00 \\
Corn grain, ground & 10.51 & 12.01 \\
Soybean meal, solvent extracted 48\% CP & 0.65 & 0.65 \\
Vitamin and mineral premix ${ }^{2}$ & 0.40 & 0.40 \\
Calcium carbonate & 0.40 & 0.40 \\
Salt & & \\
${ }^{1}$ Formulated (NRC, 2001). & & \\
${ }^{2}$ Contained 18.9\% Ca, 24.5\% NaCl, $1.6 \% \mathrm{Mg}, 0.5 \% \mathrm{~K}, 880 \mathrm{mg} / \mathrm{kg}$ of \\
Cu, $50 \mathrm{mg} / \mathrm{kg}$ of I, 25 mg/kg of Se, 3,880 mg/kg of Zn, 551,146 IU $/ \mathrm{kg}$ \\
of vitamin A, 110,229 IU/kg of vitamin $\mathrm{D}_{3}$, and 4,189 IU/kg of vitamin \\
E (HeiferSmart No Phos, Purina Animal Nutrition LLC, Shoreview, \\
MN).
\end{tabular}


Heifers had ad libitum access to fresh water. Feeding occurred once daily at $0600 \mathrm{~h}$ using the Calan gate feeding systems (American Calan Inc., Northwood, $\mathrm{NH}$ ). Every morning before feeding, any orts were weighed and the individual intakes were measured. As mentioned, rations were formulated using the NRC (2001) to be limit-fed at $2.65 \%$ of BW (DM basis) to meet requirements of a heifer weighing $250 \mathrm{~kg}$ and to target $0.8 \mathrm{~kg} / \mathrm{d}$ of ADG as recommended by Hoffman (1997) and Zanton and Heinrichs (2005). The $250 \mathrm{~kg}$ of BW was a pre-estimated average BW for heifers during the study based on age and previous herd data. Rations were adjusted every 2 wk based on the BW recorded on the last $2 \mathrm{~d}$ of the previous 2-wk interval and DM of feeds. At each feeding, coarsely ground bromegrass hay and grain mix were individually weighed for each heifer into a large tub, hand mixed, and then placed in the Calan boxes. As rations were limit-fed, heifers consumed all of their rations between daily feedings during the majority of the experimental period and sorting was not an issue. Each week, samples of the grass hay and grain mixes were taken. Each month, samples of individual concentrate mix ingredients (corn, soybean meal, CRM, and DDGS) were also taken. All feed samples were stored at $-20^{\circ} \mathrm{C}$ until processing and analysis could be completed as described under laboratory analysis.

\section{Animal Measurements and Sampling}

Body growth measurements including BW, withers height, hip height, hip width, heart girth, paunch girth, and body length were taken on 2 consecutive days at the beginning of the study and then every $2 \mathrm{wk}$ during the study at $4 \mathrm{~h}$ postfeeding. Body length was measured from the top point of the withers to the end of the ischium (Hoffman, 1997). Body condition scores were recorded every 2 wk by 4 independent observers based on a quarter-point scale with 1 being emaciated and 5 being obese (Wildman et al., 1982). Rumen fluid was collected via esophageal tubing during wk 12 and 16 on 2 consecutive days, at $4 \mathrm{~h}$ postfeeding at the same time as body measurements were being taken. After discharging the first $200 \mathrm{~mL}$ of fluid to minimize saliva contamination, approximately $50 \mathrm{~mL}$ of rumen fluid was collected. The $\mathrm{pH}$ of the samples was immediately measured using a $\mathrm{pH}$ meter (Waterproof $\mathrm{pH}$ Testr 30, Oakton Instruments, Vernon Hills, IL) and 2 aliquots $(10 \mathrm{~mL})$ were acidified with either $200 \mu \mathrm{L}$ of $50 \%$ (vol/vol) sulfuric acid or $2 \mathrm{~mL}$ of $25 \%$ (wt/ vol) meta-phosphoric acid and stored at $-20^{\circ} \mathrm{C}$ until later analysis of $\mathrm{NH}_{3}-\mathrm{N}$ and VFA. During 3 consecutive days in wk 16 of the feeding period, fecal grab and ort samples were collected for analysis of total-tract digestibility of nutrients using acid detergent insoluble ash as an internal marker. Fecal sampling time points were scheduled so that the samples represented every 3 $\mathrm{h}$ in a 24 -h feeding cycle. Samples were stored at $-20^{\circ} \mathrm{C}$ until processing and analysis.

\section{Laboratory Analysis}

Total dietary nutrient concentrations were calculated based on analyses of grass hay and grain mix for each treatment. Every 2 wk throughout the study, an aliquot of feed samples was dried for $24 \mathrm{~h}$ at $105^{\circ} \mathrm{C}$ for $\mathrm{DM}$ analysis to adjust dietary ingredient inclusion amounts and determine DMI. Samples of ground corn, soybean meal, CRM, DDGS, grass hay, CRM grain mix, and DDGS grain mix were collected once weekly and frozen at $-20^{\circ} \mathrm{C}$ until analysis. Weekly samples of feeds and grain mixes were thawed and samples from 4 consecutive weeks were composited on as-fed basis by weight. Composite samples were dried in duplicate for $48 \mathrm{~h}$ at $55^{\circ} \mathrm{C}$ in a Dispatch oven (Style V-23, Dispatch Oven Co., Minneapolis, MN), ground to 4-mm particle size with a Wiley Mill (model 3, Arthur H. Thomas Co., Philadelphia, PA), and further ground to 1-mm particle size using an ultracentrifuge mill (Brinkman Instruments Co., Westbury, NY). To correct nutrient analyses to $100 \%$ DM, 1-g aliquots of ground feed samples were dried for $4 \mathrm{~h}$ in a $105^{\circ} \mathrm{C}$ oven (model 28, Precision Scientific Co., Chicago, IL). Ash content (AOAC International, 2002 method 942.05) was determined by incinerating a 1-g sample for $8 \mathrm{~h}$ at $450^{\circ} \mathrm{C}$ in a muffle furnace (model F1730, Thermolyne Corp., Dubuque, IA; temperature controller model Wheelco 293, BarberColman Co., Rockford, IL). Organic matter was calculated as $\mathrm{OM}=(100-\%$ ash $)$. Samples were analyzed for nitrogen content via Dumas combustion analysis (AOAC International, 2002, method 968.06), on a rapid N Cube (Elementar Analysensysteme, GmbH, Hanau, Germany). Nitrogen content was then multiplied by 6.25 to calculate CP. Neutral detergent fiber (Van Soest et al., 1991) and ADF (Robertson and Van Soest, 1981; AOAC International, 2002, method 973.18) were analyzed sequentially using the Ankom 200 fiber analysis system (Ankom Technology Corp., Fairport, NY). For NDF, heat-stable $\alpha$-amylase and sodium sulfite were used (AOAC International, 2002, method 2002.04). Petroleum ether was used to determine ether extract (EE; AOAC International, 2002, method 920.39) in an Ankom XT10 fat analysis system (Ankom Technology Corp., Fairport, NY). Nonfiber carbohydrate was calculated as $\% \mathrm{NFC}=100-(\%$ ash $+\% \mathrm{CP}+\% \mathrm{NDF}$ $+\%$ EE) according to the NRC (2001). 
Dried and ground samples of grass hay, CRM and DDGS grain mixes were further composited into 5and 6-mo composites and sent to a commercial laboratory (Dairyland Laboratories Inc., Arcadia, WI) for analysis of minerals $(\mathrm{Ca}, \mathrm{Cl}, \mathrm{Mg}, \mathrm{P}, \mathrm{K}, \mathrm{Na}, \mathrm{S}, \mathrm{Fe}$, $\mathrm{Mn}, \mathrm{Mo}, \mathrm{Cu}$, and $\mathrm{Zn}$ ) and DCAD. Mineral content, excluding chloride, was determined using inductively coupled plasma spectroscopy (AOAC International, 2002). Chloride content was determined using a direct reading chloride analyzer (Corning 926, Corning Inc., Corning, NY).

Glucosinolate analysis and quantitation in the CRM was performed by a laboratory at the USDA Agricultural Research Service (Peoria, IL). Analysis methods performed on the original test feed (CRM) were similar to those described by Berhow et al. (2013). Quantitation was completed using a modified method for HPLC developed by Betz and Fox (1994). The preparation of sinigrin standards (Sigma-Aldrich Co., St. Louis, MO) was done on a molar concentration basis to determine standard curve and lower detection limits. Dried ground feed samples were extracted with methanol and analyzed using liquid chromatic MS to find glucosinolate composition, and reversed-phase HPLC at $237 \mathrm{~nm}$ was used to determine concentrations of individual glucosinolates.

Rumen fluid samples preserved with sulfuric acid were thawed and centrifuged at $30,000 \times g$ for $20 \mathrm{~min}$ at $4^{\circ} \mathrm{C}$ (centrifuge: Eppendorf 5403, Eppendorf North America, Hauppauge, NY) and analyzed for $\mathrm{NH}_{3} \mathrm{~N}$ using a colorimetric assay performed on a microplate spectrophotometer (Cary 50, Varian Inc., Walnut Creek, CA) according to Chaney and Marbach (1962). Rumen fluid samples that were preserved with $25 \%$ meta-phosphoric acid were thawed and centrifuged at $30,000 \times g$ for $20 \mathrm{~min}$ at $4^{\circ} \mathrm{C}$ and analyzed for acetate, propionate, butyrate, isobutyrate, isovalerate, and valerate concentrations using an automated GC (model 6890, Hewlett-Packard Co., Palo Alto, CA) using a flame ionization detector. Volatile fatty acids were separated on a capillary column $(15 \mathrm{~m} \times 0.25 \mathrm{~mm}$ i.d.; Nukol, 17926-01C, Supelco Inc., Bellefonte, PA) using 2-ethylbutyrate as an internal standard. The split ratio of 100:1 in the injector port was at a temperature of $250^{\circ} \mathrm{C}$ with flow rate of $1.3 \mathrm{~mL} / \mathrm{min}$ of helium. The column and detector temperature were maintained at 140 and $250^{\circ} \mathrm{C}$, respectively.

Fecal samples from all collection time points were composited for each heifer on an as-is basis by volume. Aliquots of $100 \mathrm{~mL}$ of fecal samples were taken from each time point and composited. Orts (if any were left) were collected $3 \mathrm{~d}$ during the fecal collection period. Orts were composited based on proportions of weight from each day for any heifers that had orts on multiple days. Fecal and orts composites were dried and ground and were analyzed for DM, ash, CP, NDF, and ADF as previously described for feed composites. Analysis of acid detergent insoluble ash consisted of determination ADF content (Robertson and Van Soest, 1981) and then analysis of the ash content using a modified procedure of AOAC method 935.29 (AOAC International, 2002) for all feed composites, and fecal and orts samples. Apparent total-tract digestibility calculations for DM, OM, CP, NDF, and ADF were determined according to Merchen (1988).

\section{Statistical Analysis}

All data were analyzed using SAS version 9.4 (SAS Institute Inc., Cary, NC). The MEANS procedure of SAS was used just to estimate the means and standard errors of the nutrients of the monthly feed composites.

To determine ADG for $\mathrm{BW}$ and change per day for body frame measurements, the difference was found between each data collection time point and the previous time point and then divided by the number of days in the time period [i.e., (wk 2 - wk 0)/14 d]. Gain-to-feed ratio was calculated as the ratio of ADG of BW to total DMI for each heifer during each 2-wk time interval between weight and frame measurements.

Heifer intakes, gain:feed, growth data, ADG, and rumen fermentation data were analyzed as a randomized complete block design with week as the repeated measure and the term heifer (block) as the subject using PROC MIXED procedures of SAS (Littell et al., 2006). Initial (wk 0) BW and frame measurements were used as covariate terms for each respective variable. The model included treatment, week, and treatment $\times$ week interactions. Akaike's criterion was used to determine the most suitable covariance structure in repeated measures for each parameter. Covariance structures tested were compound symmetry, first-order autoregressive, Toeplitz, and unstructured. Compound symmetry resulted in the least absolute Akaike's values and was used for the final model. Significant differences among treatments were declared at $P \leq 0.05$ and tendencies were declared at $0.05<P \leq 0.10$. Least squares means are reported for each treatment in the tables. The slice option was used to determine if differences between treatments were significant at individual weeks or time points of measurements.

The MIXED procedures of SAS were used for the analysis of total-tract digestibility of nutrients. As total-tract digestibility was analyzed only during wk 16 , the model only included treatment with block included as a random variable. 
Table 2. Nutrient composition of the test feeds (carinata meal and distillers dried grains with solubles) and ration components (grain mixes and forage) used to make the carinata meal (CRM) and distillers dried grains with solubles (DDGS) diets fed to growing Holstein heifers

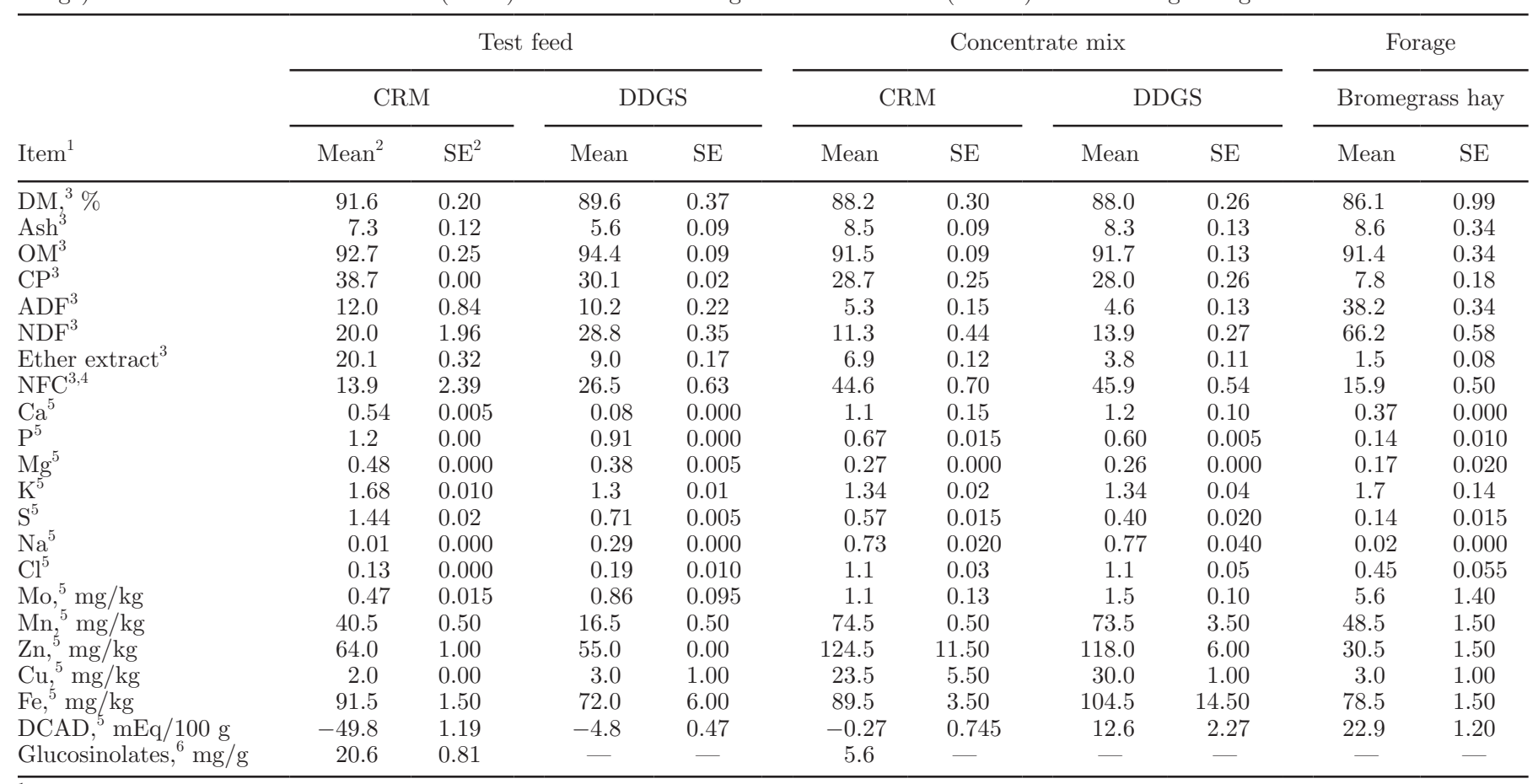

${ }_{1} \%$ of DM, unless otherwise indicated.

${ }^{2}$ The MEANS procedure of SAS (SAS Institute Inc., Cary, NC) was used to estimate the means and SE of all nutrients of the monthly feed composites, and 5- and 6-mo composites of the ration components.

${ }^{3}$ Results from monthly composite samples.

${ }^{4} \%$ of $\mathrm{NFC}=100-(\%$ ash $+\% \mathrm{CP}+\% \mathrm{NDF}+\%$ ether extract $)(\mathrm{NRC}, 2001)$.

${ }^{5}$ Results calculated from the analysis of 5- and 6-mo composites of the ration components.

${ }^{6}$ Value of the test feed from glucosinolate analysis; value for the CRM grain mix was calculated from glucosinolate analysis and inclusion rate $(10 \%)$ of the test feed in the diet. Distillers dried grains with solubles and bromegrass hay do not contain glucosinolates.

\section{RESULTS AND DISCUSSION}

\section{Feed Analysis}

Inclusion amounts of ground corn and soybean meal were slightly different to balance the diets to be isonitrogenous and isoenergetic (Table 1) because of the variation in nutrient composition among the 2 test feeds (Table 2). The nutrient composition of the grain mixes and grass hay (Table 2) was consistent during the course of the study. One exception was slight variation on DM of grass hay over the course of the study, which was due to changes in season and humidity; however, as the dietary inclusion amount of grass hay was similar between diets these DM changes did not affect our interpretation of treatment effects. The CRM grain mix EE was greater than the DDGS grain mix because of the EE content of the carinata meal, which was cold pressed. However, the amount of EE of the grain mix did not markedly increase the fat content of the CRM diet (Table 3) compared with the original formulation of the CRM diet. Generally, diets were consistent with the formulated diets; however, $\mathrm{CP}$ of both diets was $1 \%$ less than formulated because the $\mathrm{CP}$ of the hay was slightly less during the study than values used for initial diet formulations. When the nutrient composition of the ingredients based on analysis was reentered into the NRC (2001) software, the energy values of the analyzed diets were consistent with the original formulations.

\section{Heifer Growth Performance}

During the study, 1 heifer died from pneumonia, which was unrelated to treatment. Without any replacement heifer of similar size and age available, the DDGS treatment had a total of 11 heifers and the CRM treatment had 12 heifers.

Dry matter intake, BW, ADG, and gain:feed results are presented in Table 4 . There were time effects for these variables as expected in growing heifers, but there were no effects of treatment. There was an interaction 
Table 3. Overall nutrient composition of diets containing $10 \%$ carinata meal (CRM) or 10\% distillers dried grains with solubles (DDGS)

\begin{tabular}{|c|c|c|c|c|}
\hline \multirow[b]{3}{*}{ Item $^{1}$} & \multicolumn{4}{|c|}{ Diet } \\
\hline & \multicolumn{2}{|c|}{ CRM } & \multicolumn{2}{|c|}{ DDGS } \\
\hline & Mean $^{2}$ & $\mathrm{SE}^{2}$ & Mean & $\mathrm{SE}$ \\
\hline$\overline{\mathrm{DM}}{ }^{3} \%$ & 86.9 & 0.68 & 86.8 & 0.65 \\
\hline $\mathrm{Ash}^{3}$ & 8.5 & 0.21 & 8.5 & 0.22 \\
\hline $\mathrm{OM}^{3}$ & 91.5 & 0.21 & 91.5 & 0.22 \\
\hline $\mathrm{CP}^{3}$ & 15.5 & 0.15 & 15.3 & 0.15 \\
\hline $\mathrm{ADF}^{3}$ & 26.0 & 0.27 & 25.7 & 0.27 \\
\hline $\mathrm{NDF}^{3}$ & 46.0 & 0.35 & 46.9 & 0.38 \\
\hline Ether extract $^{3}$ & 3.5 & 0.05 & 2.4 & 0.06 \\
\hline $\mathrm{NFC}^{3,4}$ & 26.5 & 0.45 & 27.0 & 0.37 \\
\hline Forage $\mathrm{NDF}^{3}$ & 41.7 & 0.37 & 41.7 & 0.37 \\
\hline Nonforage $\mathrm{NDF}^{3}$ & 4.2 & 0.16 & 5.2 & 0.10 \\
\hline $\mathrm{Ca}^{3,5}$ & 0.65 & 0.055 & 0.69 & 0.035 \\
\hline $\mathrm{P}^{3,5}$ & 0.33 & 0.012 & 0.31 & 0.008 \\
\hline $\mathrm{Mg}^{3,5}$ & 0.21 & 0.013 & 0.20 & 0.013 \\
\hline $\mathrm{K}^{3,5}$ & 1.6 & 0.09 & 1.6 & 0.10 \\
\hline $\mathrm{S}^{3,5}$ & 0.29 & 0.015 & 0.23 & 0.002 \\
\hline $\mathrm{Na}^{3,5}$ & 0.28 & 0.007 & 0.30 & 0.015 \\
\hline $\mathrm{Cl}^{3,5}$ & 0.68 & 0.046 & 0.67 & 0.053 \\
\hline $\mathrm{Mo},{ }^{5} \mathrm{mg} / \mathrm{kg}$ & $\begin{array}{l}0.00 \\
3.9\end{array}$ & 0.93 & 4.0 & 0.85 \\
\hline $\mathrm{Mn},{ }^{5} \mathrm{mg} / \mathrm{kg}$ & 58.1 & 1.13 & 57.8 & 0.35 \\
\hline $\mathrm{Zn},{ }^{5} \mathrm{mg} / \mathrm{kg}$ & 65.3 & 5.20 & 62.9 & 3.17 \\
\hline $\mathrm{Cu},{ }^{5} \mathrm{mg} / \mathrm{kg}$ & 10.6 & 1.41 & 13.0 & 1.00 \\
\hline $\mathrm{Fe},{ }^{5} \mathrm{mg} / \mathrm{kg}$ & 82.6 & 0.35 & 88.1 & 6.31 \\
\hline $\mathrm{DCAD}^{5} \mathrm{mEq} / 100 \mathrm{~g}$ & 14.3 & 0.48 & 19.1 & 1.59 \\
\hline Glucosinolate, ${ }^{6} \mathrm{mg} / \mathrm{g}$ & 2.06 & - & - & - \\
\hline $\mathrm{ME},{ }^{7} \mathrm{Mcal} / \mathrm{kg}$ of DM & 2.38 & - & 2.34 & - \\
\hline $\mathrm{NE}_{\mathrm{G}},{ }^{7} \mathrm{Mcal} / \mathrm{kg}$ of DM & 0.87 & - & 0.85 & - \\
\hline
\end{tabular}

${ }_{1} \%$ of DM, unless otherwise indicated.

${ }^{2}$ The MEANS procedure of SAS (SAS Institute Inc., Cary, NC) was used just to estimate the means and $\mathrm{SE}$ of the nutrients of the monthly feed composites, and 5- and 6-mo composites of the ration components.

${ }^{3}$ Results from monthly composite samples.

${ }^{4} \%$ of $\mathrm{NFC}=100-(\%$ ash $+\% \mathrm{CP}+\% \mathrm{NDF}+\%$ ether extract $)$ (NRC, 2001).

${ }^{5}$ Results calculated from the analysis of 5- and 6-mo composites of the ration components.

${ }^{6}$ Value was calculated based on glucosinolate analysis (Table 2) and inclusion rate (10\%) of the test feed on the CRM diet.

${ }^{7}$ Values are calculated based on inputting sample nutrient analysis into ration formulations in the Dairy NRC computer program (2001, Washington, DC)

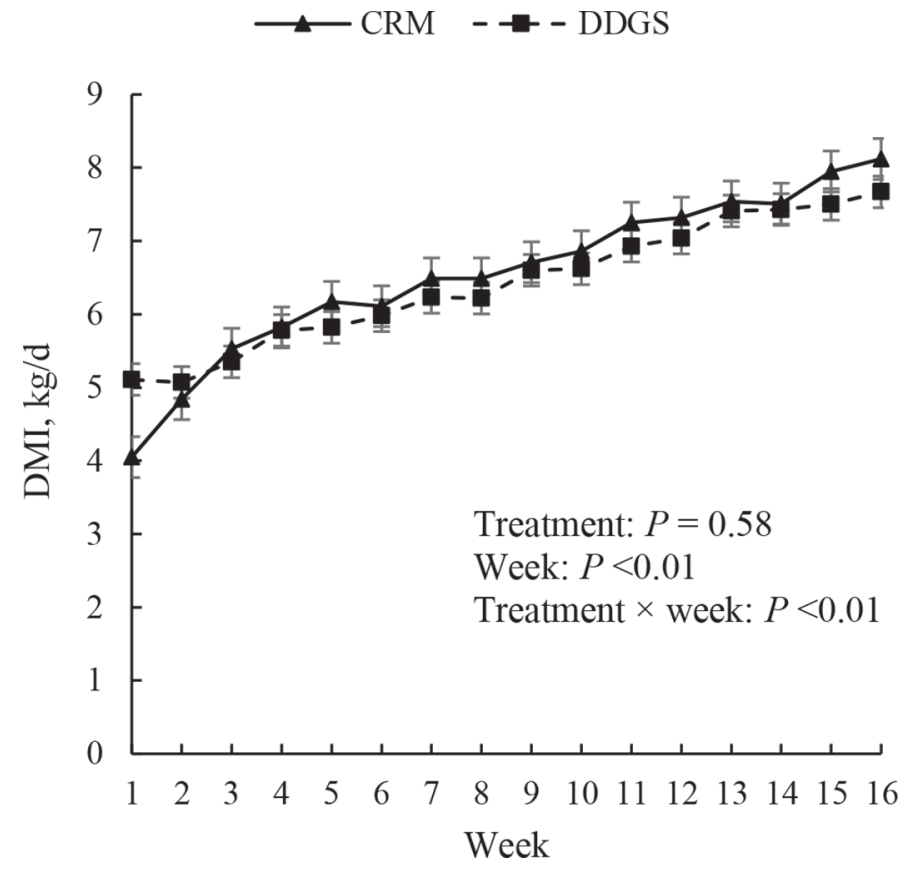

Figure 1. Dry matter intakes of growing Holstein heifers fed diets containing $10 \%$ (DM basis) carinata meal (CRM) or distillers dried grains with solubles (DDGS) over 16 wk. Error bars represent SEM $=0.16$.

of treatment by week for DMI, and gain:feed ratio because during the first week of the study the DMI of the heifers on the DDGS diet was $1 \mathrm{~kg}$ greater than the heifers in the CRM diet (Figure 1). However, CRM intakes quickly rebounded for the rest of the study. This demonstrated that after initial adjustment to the treatment ration, intakes were not compromised by feeding CRM and agreed with findings by Lawrence et al. (2016), who fed camelina meal to heifers. Although the $\mathrm{CP}$ content of the diet was less than the originally formulated diets, the targeted ADG of $0.8 \mathrm{~kg} / \mathrm{d}$ was still achieved. This was because the CP of the diets still was above the ideal amount of CP to achieve maximum microbial fermentation (Tamminga, 1992).

Table 4. Dry matter intake, BW, ADG, and gain:feed ratios for Holstein heifers fed diets with 10\% carinata meal (CRM) or distillers dried grains with solubles (DDGS)

\begin{tabular}{|c|c|c|c|c|c|c|}
\hline \multirow[b]{2}{*}{ Item } & \multicolumn{2}{|c|}{ Treatment } & \multirow[b]{2}{*}{ SEM } & \multicolumn{3}{|c|}{$P$-value } \\
\hline & $\mathrm{CRM}$ & DDGS & & Treatment & Week & Treatment $\times$ week \\
\hline \multicolumn{7}{|l|}{$\overline{\mathrm{BW}}, \mathrm{kg}$} \\
\hline Mean & 269.9 & 268.9 & 1.4 & 0.61 & $<0.01$ & 0.99 \\
\hline Initial & 221.0 & 214.8 & 9.5 & 0.89 & & \\
\hline Final & 321.5 & 313.8 & 8.33 & 0.74 & & \\
\hline $\mathrm{ADG}, \mathrm{kg} / \mathrm{d}$ & 0.837 & 0.825 & 0.0282 & 0.76 & $<0.01$ & 0.97 \\
\hline DMI, kg/d & 6.55 & 6.42 & 0.159 & 0.58 & $<0.01$ & $<0.01$ \\
\hline Gain:feed & 0.131 & 0.130 & 0.0037 & 0.93 & $<0.01$ & $<0.01$ \\
\hline
\end{tabular}


Frame size measurements and BCS are shown in Table 5 . No treatment by week interactions were found for any of the frame growth measurements. An increase occurred over the time for the frame size measurements as expected in growing animals. Additionally, there were no effects of treatment in change per day for any of the growth variables measured. To our knowledge, this is the first study on the effects of feeding CRM to growing dairy heifers. Only one study is available where carinata meal pellets were fed to Angus crossbred beef heifers (Schulmeister et al., 2016) at $0.3 \%$ of the BW (as-fed basis) where the researchers observed an increase of $57 \%$ in ADG compared with beef heifers fed with only grass. Although we did not observe differences between treatments in the current study, both groups of heifers achieved the target ADG of 0.8 $\mathrm{kg} / \mathrm{d}$, which is the optimal rate of gain for growing heifers (Zanton and Heinrichs, 2005). Additionally, studies with dairy heifers (Lawrence et al., 2016) and beef heifers (Grings et al., 2014) on feeding camelina meal (which has comparable nutrient composition to CRM) compared with DDGS also found no differences in growth performance. However, the ADG observed in the present study is greater than the observed in dairy heifers fed camelina meal (Lawrence et al., 2016). Overall frame growth and size were normal and comparable to other feeding studies by our research group with heifers in this age range (Anderson et al., 2015; Lawrence et al., 2016; Manthey et al., 2016).

\section{Rumen Fermentation Characteristics}

Collection of rumen samples via esophageal tubing at single time point in a day is not an optimal or ideal method of collection. However, as this was one of the first feeding studies on feeding CRM to heifers, we considered it valuable to determine at a preliminary level if rumen fermentation was affected (Table 6). There was concern that the glucosinolates and longchain fatty acids in the CRM diet may negatively affect rumen microorganism and fermentation. Although acetate concentrations were greater in the rumen fluid samples of the heifers fed CRM and butyrate rumen fluid concentrations were greater in heifers fed DDGS,

Table 5. Frame size measurements and BCS for Holstein heifers fed diets with $10 \%$ carinata meal (CRM) or distillers dried grains with solubles (DDGS)

\begin{tabular}{|c|c|c|c|c|c|c|}
\hline \multirow[b]{2}{*}{ Item } & \multicolumn{2}{|c|}{ Treatment } & \multirow[b]{2}{*}{ SEM } & \multicolumn{3}{|c|}{$P$-value } \\
\hline & $\mathrm{CRM}$ & DDGS & & Treatment & Week & Treatment $\times$ week \\
\hline \multicolumn{7}{|c|}{ Withers height, cm } \\
\hline Mean & 122.8 & 123.4 & 0.53 & 0.46 & \multirow[t]{3}{*}{$<0.01$} & \multirow[t]{3}{*}{0.22} \\
\hline Initial & 115.7 & 115.6 & 0.85 & 0.57 & & \\
\hline Final & 129.0 & 128.3 & 0.94 & 0.60 & & \\
\hline Change, $\mathrm{cm} / \mathrm{d}$ & 0.11 & 0.11 & 0.005 & 0.62 & 0.72 & 0.21 \\
\hline \multicolumn{7}{|l|}{ Hip height, cm } \\
\hline Mean & 126.0 & 126.4 & 0.27 & 0.30 & \multirow[t]{3}{*}{$<0.01$} & \multirow[t]{3}{*}{0.43} \\
\hline Initial & 120.3 & 119.9 & 0.99 & 0.75 & & \\
\hline Final & 131.9 & 131.5 & 0.78 & 0.56 & & \\
\hline Change, $\mathrm{cm} / \mathrm{d}$ & 0.10 & 0.10 & 0.004 & 0.98 & $<0.01$ & 0.44 \\
\hline \multicolumn{7}{|l|}{ Body length, cm } \\
\hline Mean & 114.9 & 114.6 & 0.73 & 0.76 & \multirow[t]{3}{*}{$<0.01$} & \multirow[t]{3}{*}{0.84} \\
\hline Initial & 106.1 & 105.6 & 1.4 & 0.99 & & \\
\hline Final & 125.0 & 124.9 & 0.98 & 0.82 & & \\
\hline Change, $\mathrm{cm} / \mathrm{d}$ & 0.16 & 0.16 & 0.013 & 0.86 & 0.05 & 0.68 \\
\hline \multicolumn{7}{|l|}{ Heart girth, $\mathrm{cm}$} \\
\hline Mean & 145.6 & 145.2 & 0.53 & 0.64 & \multirow{3}{*}{$<0.01$} & \multirow{2}{*}{0.68} \\
\hline Initial & 135.4 & 134.2 & 1.00 & 0.67 & & \\
\hline Final & 156.7 & 154.6 & 1.03 & 0.36 & & \\
\hline Change, $\mathrm{cm} / \mathrm{d}$ & 0.18 & 0.17 & 0.008 & 0.48 & $<0.01$ & 0.52 \\
\hline \multicolumn{7}{|l|}{ Hip width, cm } \\
\hline Mean & 38.0 & 38.2 & 0.28 & 0.47 & \multirow[t]{3}{*}{$<0.01$} & \multirow[t]{3}{*}{0.82} \\
\hline Initial & 34.3 & 34.3 & 0.28 & 0.84 & & \\
\hline Final & 41.5 & 41.8 & 0.48 & 0.15 & & \\
\hline Change, $\mathrm{cm} / \mathrm{d}$ & 0.06 & 0.06 & 0.003 & 0.44 & 0.33 & 0.67 \\
\hline \multicolumn{7}{|l|}{$\mathrm{BCS}^{1}$} \\
\hline Mean & 3.0 & 3.0 & 0.01 & 0.47 & \multirow{3}{*}{$<0.01$} & \multirow[t]{3}{*}{0.82} \\
\hline Initial & 3.0 & 2.9 & 0.03 & 0.05 & & \\
\hline Final & 3.0 & 3.1 & 0.04 & 0.89 & & \\
\hline
\end{tabular}

${ }^{1}$ Body condition scoring was on a scale of 1 to 5 with 1 being emaciated and 5 being obese (Wildman et al., 1982). 
Table 6. Rumen fermentation characteristics of growing Holstein heifers fed diets with $10 \%$ carinata meal (CRM) or distillers dried grains with solubles (DDGS)

\begin{tabular}{|c|c|c|c|c|c|c|}
\hline \multirow[b]{2}{*}{ Item } & \multicolumn{2}{|c|}{ Treatment } & \multirow[b]{2}{*}{ SEM } & \multicolumn{3}{|c|}{$P$-value } \\
\hline & CRM & DDGS & & Treatment & Week & $\begin{array}{c}\text { Treatment } \\
\times \text { week }\end{array}$ \\
\hline$\overline{\mathrm{pH}}$ & 7.0 & 6.9 & 0.07 & 0.19 & 0.44 & 0.15 \\
\hline $\mathrm{NH}_{3}-\mathrm{N}, \mathrm{mg} / \mathrm{dL}$ & 17.6 & 15.7 & 0.99 & 0.18 & 0.67 & 0.20 \\
\hline Total VFA, mM & 85.5 & 86.9 & 4.24 & 0.81 & 0.24 & 0.11 \\
\hline Acetate, $\mathrm{mmol} / 100 \mathrm{mmol}$ & 67.2 & 65.8 & 0.27 & $<0.01$ & 0.74 & 0.99 \\
\hline Propionate, $\mathrm{mmol} / 100 \mathrm{mmol}$ & 21.3 & 21.6 & 0.33 & 0.55 & 0.06 & 0.49 \\
\hline Isobutyrate, $\mathrm{mmol} / 100 \mathrm{mmol}$ & 0.65 & 0.62 & 0.106 & 0.82 & $<0.01$ & 0.75 \\
\hline Butyrate, $\mathrm{mmol} / 100 \mathrm{mmol}$ & 8.6 & 9.8 & 0.21 & $<0.01$ & 0.09 & 0.93 \\
\hline Isovalerate, $\mathrm{mmol} / 100 \mathrm{mmol}$ & 1.3 & 1.2 & 0.05 & 0.13 & 0.54 & $<0.01$ \\
\hline Valerate, $\mathrm{mmol} / 100 \mathrm{mmol}$ & 0.89 & 0.94 & 0.028 & 0.18 & 0.37 & 0.30 \\
\hline Acetate:propionate & 3.18 & 3.08 & 0.058 & 0.22 & 0.15 & 0.59 \\
\hline
\end{tabular}

no differences were found for propionate concentrations between treatments. Additionally, the VFA proportions and ammonia concentrations were comparable to other studies that also collected rumen fluid via esophageal tubing by our research group with heifers of this age (Lawrence et al., 2016; Manthey et al., 2016). However, because of sampling methodology, these results should be regarded with caution and more research is warranted with cannulated heifers or cows to substantiate that feeding CRM at $10 \%$ of diet DM does not negatively alter rumen fermentation.

\section{Apparent Total-Tract Digestion of Nutrients}

Apparent total-tract nutrient digestibilities of nutrients are presented in Table 7. Crude protein digestibility was similar among treatments, whereas digestibility of DM, OM, NDF, and ADF was greater for the DDGS diet. Overall apparent total-tract nutrient digestibility values were also comparable to other studies with this age of dairy replacement heifers (Anderson et al., 2015; Lawrence et al., 2016; Manthey et al., 2016). The relatively small differences between treatments in fiber and consequentially DM and OM digestibility could be attributed to the difference in nonforage fiber content between the 2 test ingredients. Another possibility is the difference of DCAD between DDGS and CRM grain mixes. Martins et al. (2016) found a positive association between DCAD and NDF total-tract digestibility that could be attributed to major activity of cellulolytic bacteria. In this study, the greater butyrate proportion in the rumen fluid of the heifers in DDGS may support this hypothesis. However, the differences in total-tract digestibility were not large enough or of enough biological significance to affect the overall growth performance or gain:feed of the heifers. We hypothesized that the $\mathrm{CP}$ total-tract digestibility on the
CRM diet may be greater compared with DDGS diet because of differences in the RDP content (Lawrence and Anderson, 2015), but found in the current study that $\mathrm{CP}$ digestibility was similar. It is speculated that the difference in RDP was compensated for by the high digestion of RUP from DDGS in the intestines (Kleinschmit et al., 2007).

\section{CONCLUSIONS}

This research study is one of the first, that we are aware of, on feeding CRM to growing dairy heifers. In this study, we showed that despite containing some glucosinolates, heifers can adapt to the taste of CRM and DMI will not be affected for long. However, producers need to be aware that heifers may initially need an adaptation period of 1 or $2 \mathrm{wk}$ to adjust to the flavor of CRM. Although, rumen fermentation and total-tract digestibility of nutrients had some minor differences compared with the DDGS diet, body frame growth and ADG were maintained at recommended rates throughout the study. In this initial study, a limit-feeding strategy was used to control overall intakes. More research may be warranted using other feeding strategies such

Table 7. Total-tract digestion of nutrients for growing Holstein heifers fed diets with $10 \%$ of carinata meal (CRM) or distillers dried grains with solubles (DDGS)

\begin{tabular}{lccrcc}
\hline & \multicolumn{2}{c}{ Treatment } & & \multicolumn{2}{c}{$P$-value } \\
\cline { 2 - 3 } \cline { 5 - 5 } Item, \% digested & CRM & DDGS & SEM & Treatment \\
\hline DM & 67.4 & 69.8 & 2.21 & $<0.05$ \\
OM & 70.2 & 72.5 & 1.93 & 0.05 \\
CP & 74.9 & 75.6 & 0.80 & 0.54 \\
NDF & 60.8 & 64.5 & 1.78 & $<0.01$ \\
ADF & 68.4 & 70.9 & 1.42 & $<0.05$ \\
\hline
\end{tabular}


as diets fed ad libitum as TMR. Also, more research is needed to determine interactions with other types of feeds and evaluate feeding cold-pressed versus solventextracted carinata meal. Overall, this initial research on feeding carinata meal demonstrated that it is a viable protein and energy source for dairy heifers that can maintain growth performance when included at $10 \%$ of diet DM. Carinata meal shows potential as a co-product of the biofuels industry that can be used as a new feedstuff for growing dairy heifers.

\section{ACKNOWLEDGMENTS}

We thank Mark Berhow (USDA-ARS, Peoria, IL) for his assistance with glucosinolate analysis of test feeds. This research was funded by the South Dakota Oilseed Initiative with support of the South Dakota State University Agricultural Experiment Station. It contributes to goals of the USDA Multi-State Research Project NC1204: Advancement of Brassica carinata.

\section{REFERENCES}

Anderson, J. L., K. F. Kalscheur, A. D. Garcia, and D. J. Schingoethe. 2015. Feeding fat from distillers dried grains with solubles to dairy heifers: I. Effects on growth performance and total tract digestibility of nutrients. J. Dairy Sci. 98:5699-5708. https://doi.org/10 $.3168 /$ jds.2014-9162.

AOAC International. 2002. Official Methods of Analysis. 17th ed. AOAC International, Gaithersburg, MD.

Benz, S. A. 2010. Food and Drug Administration-Department of Health and Human Services. Accessed Jul. 15, 2014. http://agr .mt.gov/agr/ProducerCheckoff/Camelina/pdf/FDA_exception_9 $-2-10$.pdf.

Berhow, M. A., U. Polat, J. A. Glinski, M. Glensk, S. F. Vaughn, T. Isbell, I. Ayala-Diaz, L. Marek, and C. Gardner. 2013. Optimized analysis and quantification of glucosinolates from Camelina sativa seeds by reverse-phase liquid chromatography. Ind. Crops Prod. 43:119-125. https://doi.org/10.1016/j.indcrop.2012.07.018.

Betz, J. M., and W. D. Fox. 1994. High-performance liquid chromatographic determination of glucosinolates in Brassica vegetables. Pages 181-195 in Food Chemicals for Cancer Prevention I: Fruits and Vegetables, M-T. Huang, T. Osawa, C-T. Ho, and A. T. Roen, ed. ACS Symposia series 546, ACS publications, Washington, DC.

Brown, D. 2014. Plants poisonous to livestock and other animals. Department of Animal Science. Cornell University. Accessed Sep. 9, 2015. http://poisonousplants.ansci.cornell.edu/toxicagents/ glucosin.html.

Cardone, M., M. Mazzinhcini, S. Menini, V. Rocco, A. Senatore, M. Seggiani, and S. Vitolo. 2003. Brassica carinata as an alternative oil crop for the production of biodiesel in Italy: Agronomic evaluation, fuel production by transesterification and characterization. Biomass Bioenergy 25:623-636. https://doi.org/10.1016/S0961 -9534(03)00058-8.

Chaney, A. L., and E. P. Marbach. 1962. Modified reagents for determination of urea and ammonia. Clin. Chem. 8:130-132.

Duncan, A. J., and J. A. Milne. 1992. Rumen microbial degradation of allyl cyanide as a possible explanation for the tolerance of sheep to brassica-derived glucosinolates. J. Sci. Food Agric. 58:15-19. https://doi.org/10.1002/jsfa.2740580104.

Duncan, A. J., and J. A. Milne. 1993. Effects of oral administration of brassica secondary metabolites, ally cyanide, allyl isothyiocyanate and dimethyl disulphide, on the voluntary food intake and metabolism of sheep. Br. J. Nutr. 70:631-645.

Enjalbert, J., S. Zheng, J. J. Johnson, J. L. Mullen, P. F. Byrne, and J. K. McKay. 2013. Brassicaceae germplasm diversity for agronomic and seed quality traits under drought stress. Ind. Crops Prod. 47:176-185. https://doi.org/10.1016/j.indcrop.2013.02.037.

Forss, D. A., and T. N. Barry. 1983. Observations on nitrile production during autolysis of kale and swedes, and their stability during incubation with rumen fluid. J. Sci. Food Agric. 34:1077-1084. https://doi.org/10.1002/jsfa.2740341007.

Gabler, M. T., P. R. Tozer, and A. J. Heinrichs. 2000. Development of a cost analysis spreadsheet for calculating the cost to raise a replacement dairy heifer. J. Dairy Sci. 83:1104-1109. https://doi .org/10.3168/jds.S0022-0302(00)74975-7.

Geertmann, E. J. M., H. J. M. Op den Camp, H. J. Jansen, R. G. L. Op den Camp, J. H. J. Huis in't Veld, and G. D. Vogels. 1994. Degradation of L-5-vinyloxazolidine-2-thione, a goitrogenic product from rapeseed, by rumen microorganisms. J. Environ. Sci. Health A 29:2009-2021. https://doi.org/10.1080/10934529409376161.

Gould, B. 2017. Dairy Marketing and Risk Management Program. Prices of Grains, Livestock Products and Hay. Agricultural and Applied Economics, UW Madison. Accessed Jul. 26, 2017. http:// future.aae.wisc.edu/tab/feed.html\#80.

Grings, E. E., A. Sackey, and G. A. Perry. 2014. Comparison of camelina meal and DDGS in the diets of replacement beef heifers. J. Dairy Sci. 97(E-Suppl. 1):725.

Hoffman, P. C. 1997. Optimum body size of Holstein replacement heifers. J. Anim. Sci. 75:836-845.

Kleinschmit, D. H., J. L. Anderson, D. J. Schingoethe, K. F. Kalscheur, and A. R. Hippen. 2007. Ruminal and intestinal degradability of distillers grains plus solubles varies by source. J. Dairy Sci. 90:2909-2918. https://doi.org/10.3168/jds.2006-613.

Lawrence, R., and J. L. Anderson. 2015. Ruminal degradation and intestinal digestibility of camelina and carinata meal compared with other protein resources. J. Dairy Sci. 98(Suppl. 2):459. (Abstr.)

Lawrence, R. D., J. L. Anderson, and J. A. Clapper. 2016. Evaluation of camelina meal as a feedstuff for growing dairy heifers. J. Dairy Sci. 99:6215-6228. https://doi.org/10.3168/jds.2016-10876.

Littell, R. C., G. A. Milliken, W. W. Stroup, R. D. Wolfinger, and O. Schabenberger. 2006. SAS for Mixed Models, 2nd ed. SAS Institute Inc., Cary, NC.

Majak, W. 2001. Review of toxic glycosides in rangeland and pasture forages. J. Range Manage. 54:494-498.

Manthey, A. K., J. L. Anderson, and G. A. Perry. 2016. Feeding distillers dried grains in replacement of forage in limit-fed dairy heifer rations: Effects on growth performance, rumen fermentation, and total tract digestibility of nutrients. J. Dairy Sci. 99:7206-7215. https://doi.org/10.3168/jds.2015-10785.

Marillia, E., T. Francis, K. C. Falk, M. Smith, and D. C. Taylor. 2014. Palliser's promise: Brassica carinata, an emerging western Canadian crop for delivery of new bio-industrial oil feedstocks. Biocatal. Agric. Biotechnol. 3:56-74. https://doi.org/10.1016/j .bcab.2013.09.012.

Martins, C. M. M. R., M. A. Arcari, K. C. Welter, J. L. Gonçalves, and M. V. Santos. 2016. Effect of dietary cation-anion difference on ruminal metabolism, total apparent digestibility, blood and renal acid-base regulation in lactating dairy cows. Animal 10:64-74. https://doi.org/10.1017/S1751731115001548.

Merchen, N. R. 1988. Digestion, Absorption and Excretion in Ruminants. Pages 182-189 in The Ruminant Animal: Digestive Physiology and Nutrition. D. C. Church, ed. Prentice Hall Inc., Upper Saddle River, NJ.

NRC. 2001. Nutrient Requirements of Dairy Cattle. 7th rev. ed. Natl Acad. Press, Washington, DC.

Robertson, J. B., and P. J. Van Soest. 1981. The detergent system of analysis and its application to human foods. Pages 123-158 in The Analysis of Dietary Fiber in Food. W. P. T. James and O. Theander, ed. Marcel Dekker Inc., New York, NY.

Schulmeister, T. M., M. Ruiz-Moreno, J. Benitez, M. E. Garcia-Ascolani, F. M. Ciriaco, D. D. Henry, J. C. B. Dubeux, G. C. Lamb, 
and N. DiLorenzo. 2016. Evaluation of Brassica carinata meal as protein supplement for growing beef heifers. J. Anim. Sci. 94(ESuppl. 5):769.

Tamminga, S. 1992. Nutrition management of dairy cows as a contribution to pollution control. J. Dairy Sci. 75:345-357. https://doi .org/10.3168/jds.S0022-0302(92)77770-4.

Tozer, P. R., and A. J. Heinrichs. 2001. What affects the cost of raising replacement dairy heifers: A multiple-component analysis. J. Dairy Sci. 84:1836-1844. https://doi.org/10.3168/jds.S0022 $-0302(01) 74623-1$.

Tripathi, M. K., and A. S. Mishra. 2007. Glucosinolates in animal nutrition: A review. Anim. Feed Sci. Tech. 132:1-27. https://doi .org/10.1016/j.anifeedsci.2006.03.003.

Tsao, R., Q. Yu, I. Friesen, J. Potter, and M. Chiba. 2000. Factors affecting the dissolution and degradation of Oriental mustard-derived sinigrin and allyl isothiocyanate in aqueous media. J. Agric. Food Chem. 48:1898-1902. https://doi.org/10.1021/jf9906578.
US Department of Energy. 2015. Multi-year program plan 2015: Government Printing Office, Washington, DC. DOE/EE-1193.

Van Soest, P. J., J. B. Robertson, and B. A. Lewis. 1991. Methods for dietary fiber, neutral detergent fiber, and non-starch polysaccharides in relation to animal nutrition. J. Dairy Sci. 74:3583-3597. https://doi.org/10.3168/jds.S0022-0302(91)78551-2.

Wildman, E. E., G. M. Jones, P. E. Wagner, R. L. Boman, H. F. Troutt Jr., and T. N. Lesch. 1982. A dairy cow body condition scoring system and its relationship to standard production characteristics. J. Dairy Sci. 65:495-501. https://doi.org/10.3168/jds .S0022-0302(82)82223-6.

Zanton, G. I., and A. J. Heinrichs. 2005. Meta-analysis to assess effect of prepubertal average daily gain of Holstein heifers on firstlactation production. J. Dairy Sci. 88:3860-3867. https://doi.org/ 10.3168/jds.S0022-0302(05)73071-X. 